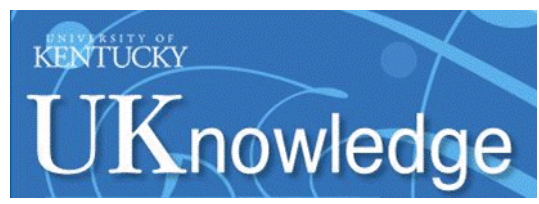

University of Kentucky

UKnowledge

\title{
Role of Competition in Restoring Resource Poor Arid Systems Dominated by Invasive Grasses
}

S. Mangla

Oregon State University

R. L. Sheley

U.S. Department of Agriculture

J. J. James

U.S. Department of Agriculture

S. R. Radosevich

Oregon State University

Follow this and additional works at: https://uknowledge.uky.edu/igc

Part of the Plant Sciences Commons, and the Soil Science Commons

This document is available at https://uknowledge.uky.edu/igc/22/2-3/2

The XXII International Grassland Congress (Revitalising Grasslands to Sustain Our Communities) took place in Sydney, Australia from September 15 through September 19, 2013. Proceedings Editors: David L. Michalk, Geoffrey D. Millar, Warwick B. Badgery, and Kim M. Broadfoot

Publisher: New South Wales Department of Primary Industry, Kite St., Orange New South Wales, Australia

This Event is brought to you for free and open access by the Plant and Soil Sciences at UKnowledge. It has been accepted for inclusion in International Grassland Congress Proceedings by an authorized administrator of UKnowledge. For more information, please contact UKnowledge@lsv.uky.edu. 


\title{
Role of competition in restoring resource poor arid systems dominated by invasive grasses
}

\author{
S Mangla ${ }^{\mathrm{A}}, R_{\mathrm{L}}$ Sheley ${ }^{\mathrm{B}}, \mathrm{JJ} \mathrm{James}^{\mathrm{B}}$ and SR Radosevich ${ }^{\mathrm{C}}$ \\ ${ }^{A}$ Environmental Science, Oregon State University, Corvallis, OR 97331, USA \\ B USDA-Agricultural Research Service, Eastern Oregon Agricultural Research Center, 67826-A Hwy 205, \\ Burns, OR 97720, USA \\ ${ }^{C}$ Forest Ecosystems and Society, Oregon State University, Corvallis, OR 97331, USA \\ Contact email: seema.mangla@oregonstate.edu
}

\begin{abstract}
An understanding of competition intensity and importance may be a useful step in helping managers understands how to prioritize restoration efforts in resource poor environments within the semi-arid steppe. The aims of this study were to quantify the intensity of competition among invasive annual grasses and native perennial bunchgrasses, and determine the importance of competition in explaining variation in target plant biomass and survivorship in a Wyoming big sagebrush steppe community type in southeastern Oregon, USA. Addition series experiments were conducted in 2008 and 2009 among four species. Treatments consisted of monoculture densities of each species to assess intraspecific competition, and mixtures of two, three and four species (interspecific competition), producing varying total densities and species proportions. We found no evidence that intensity of intra- or inter-specific competition were significant for the first two years species were establishing, regardless of the density used as the independent variable. Our results indicate that neither the intensity of competition nor the importance of competition explained variation in target plant biomass and survivorship for the first two years plants were establishing. Instead abiotic factors may have an overriding influence on plant biomass and survivorship. We propose four scenarios which may apply to semi-arid environments during the initial phase of restoration.
\end{abstract}

Keywords: Competition, invasive grasses, resource poor arid systems, sagebrush steppe, restoration.

\section{Introduction}

The role of competition in controlling plant dominance in resource poor environments remains poorly understood. Some authors have argued that competition is minimal or non-existent under high environmental stress (Grime 1973), while others suggested that the strength of competition is of equal magnitude in habitats of both high and low productivity (Newman 1973; Tilman 1980). Understanding competition intensity and importance is a central barrier to developing restoration strategies, especially in resource poor environments (Brooker and Kikividze 2008; Grace 1991; Tikka et al. 2001).

A better understanding of competition intensity and importance may allow advancements in ecology that could be particularly important in identifying how we link ecology to management and restoration of resource poor systems. For example, invasion by exotic annual grasses such as cheatgrass and medusahead, have been identified as the greatest ecological threat to the native vegetation of the semi-arid steppe of the North America (D'Antonio and Vitousek 1992). While competition is assumed to play an important role in limiting success, harsh abiotic conditions such as drought and cold stress also influence restoration outcomes (Allen 1989). Although several studies have indicated that invasive annual grasses are more competitive than grass species native to North America (Humphrey and
Schupp 2004), most information was derived from studies conducted on relatively productive grassland sites or under optimal environmental conditions. Therefore, a more complete understanding of competition intensity and importance may be a useful step in helping managers understands how to prioritize restoration efforts in resource poor environments within the semi-arid steppe.

The objectives of this study were to: (1) quantify the intensity of competition among invasive annual grasses and native perennial bunchgrasses; and (2) determine the importance of competition in explaining variation in target plant biomass and survivorship in an arid, resource poor system. We used an addition series competition design that allows quantification of the intensity and importance of competitive interactions (Spitters 1983; Welden and Slauson 1986).

The specific hypotheses tested were:

- competition would be intense among invasive and native plants; but

- competition would be unimportant in explaining variation in target plant biomass and survivorship relative to all other factors driving variation in these two parameters.

Our rationale for these hypotheses was based on the theory that in resource poor environments resources are 
limited (by definition) and competition may be intense among species, but because there are a number of other factors determining plant fitness, competition may not be important.

\section{Material and Methods}

\section{Study site and environmental conditions}

The study was conducted at Wyoming big sagebrush (Artemisia tridentata subsp. wyomingensis [Beetle \& A. Young] S. L. Welsh) - steppe community type in southeastern Oregon $\left(43^{\circ} 32 \mathrm{~N}, 118^{\circ} \mathrm{g} \mathrm{W}\right)$, Burns, Oregon, USA. Soils at the research site were a Risley cobley loam (fine, montmorillonitic, mesic Xeric Haplargid), our site had a 15 to $20 \%$ southerly slope. Environmental conditions were monitored daily from April 2008 through August 2009 using HOBO data loggers installed at the research site. Daily weather data was averaged each month and long-term weather data (1897-2009) were also compiled.

\section{Site preparation and study species}

In spring 2008, before the experiment was initiated, we applied glyphosate [ $\mathrm{N}$-(phosphonomethyl) glycine] at 0.85 $\mathrm{kg}$ a.i./ha to kill existing vegetation. Invasive annual species selected for this study were cheatgrass (Bromus tectorum L.) and medusahead (Taeniatherum caputmedusae L. Nevski). These plants are native to Eurasia and the Mediterranean region, respectively. They are among the most invasive plants in the Intermountain West. Bluebunch wheatgrass (Pseudoroegneria spicata (Pursh) A) and Sandberg's bluegrass (Poa secunda J. Presl), two native perennial species of the Intermountain West, were selected because they are common subdominant plant species in the region.

\section{Plant-plant interaction experiments}

Addition series experiments were conducted in 2008 and 2009 among the four species. Treatments consisted of monoculture densities of each species to assess intraspecific competition, and mixtures of two, three and four species (interspecific competition), producing varying total densities and species proportions (Spitters, 1983). 5 seeding densities of each of the 4 species were arranged in all possible combinations of $0,1,10,100$ and 1000 seeds $/ \mathrm{m}^{2}$ for a total of 625 plots $\left(5^{4}=625\right)$ in each replication. Therefore, total density ranged from 0 to 4000 seeds $/ \mathrm{m}^{2}$. Density combinations were completely randomized and replicated three times (625 x 3 reps=1875 plots). On May 14,2008 , monocultures and mixtures of each species were planted by randomly broadcasting the seeds on $1 \mathrm{~m}^{2}$ plots.

\section{Sampling}

In spring 2008, the number of seedlings of each species that emerged were counted in each plot and recorded as initial density. Biomass was harvested 110 days after seeding. The above-ground biomass of each individual was weighed after drying for 48 hours at $60^{\circ} \mathrm{C}$. Biomass harvested from each plot was returned to the plot from which it was collected. Plants that were not harvested continued to grow. The field was left undisturbed until spring 2009. The final density in 2008 was used as the initial density for 2009. A second harvest was collected on July 30, 2009 when the plants began to disperse seeds. The harvest proceeded as in 2008. Survivorship was calculated for each year as the ratio of final density over initial density.

\section{Statistical analyses and model fitting}

Multiple linear regression was performed using seeding, initial, and final densities $(\mathrm{N})$ of each species as independent variables and shoot biomass (W) as the dependent variable (Spitters, 1983). The following regressions equations were used to predict shoot biomass:

- $\mathrm{Wm}=\beta \mathrm{m} 0+\beta \mathrm{mm} \mathrm{Nm}+\beta \mathrm{mc} \mathrm{Nc}+\beta \mathrm{mb} \mathrm{Nb}+\beta \mathrm{ms} \mathrm{Ns}$ (medusahead)

- $\mathrm{Wc}=\beta \mathrm{c} 0+\beta \mathrm{cc} \mathrm{Nc}+\beta \mathrm{cm} \mathrm{Nm}+\beta \mathrm{cb} \mathrm{Nb}+\beta \mathrm{cs} \mathrm{Ns}$ (cheatgrass)

- $\mathrm{Wb}=\beta \mathrm{b} 0+\beta \mathrm{bb} \mathrm{Nb}+\beta \mathrm{bm} \mathrm{Nm}+\beta b c \mathrm{Nc}+\beta b \mathrm{ss}$ (bluebunch wheatgrass)

- $\mathrm{Ws}=\beta \mathrm{s} 0+\beta \mathrm{ss} \mathrm{Ns}+\beta \mathrm{sm} \mathrm{Nm}+\beta \mathrm{sc} \mathrm{Nc}+\beta \mathrm{sb} \mathrm{Nb}$ (Sandberg's bluegrass)

where: $\mathrm{W}_{\mathrm{m}}, \mathrm{W}_{\mathrm{c}}, \mathrm{W}_{\mathrm{b}}$ and $\mathrm{W}_{\mathrm{s}}$ represent the average shoot biomass per plant for medusahead, cheatgrass, bluebunch wheatgrass and Sandberg's bluegrass, respectively. The regression coefficients $\beta_{\mathrm{m} 0}, \beta_{\mathrm{c} 0}, \beta_{\mathrm{b} 0}$ and $\beta_{\mathrm{s} 0}$ represent the $y$ intercept which is the estimate of maximum shoot biomass of an isolated individual. $\beta_{\mathrm{mm}}, \beta_{\mathrm{cc}}, \beta_{\mathrm{bb}}, \beta_{\mathrm{ss}}$ represent intraspecific competition. Interspecific competition was estimated by $\beta_{\mathrm{mc}}, \beta_{\mathrm{mb}}, \beta_{\mathrm{ms},} \beta_{\mathrm{bc}}, \beta_{\mathrm{bs}}, \beta_{\mathrm{cs}}$. A positive response denotes facilitation, whereas a negative response denotes competition. Similarly, multiple regression equations were used to predict survivorship using seeding density as the independent variable because initial and final densities were used to calculate survivorship. The coefficient of determination $\left(\mathrm{R}^{2}\right)$ estimates the proportion of variation in the dependent variable (shoot biomass or survivorship) that is described by the regression model. $\mathrm{R}^{2}$ value from each regression was used to determine the importance of competition in explaining variation in target plant biomass and survivorship (Spitters 1983; Weldon and Slauson 1986). Statistical computations were performed using SPlus software.

\section{Results}

\section{Competition Intensity}

Seeding density predicting target plant biomass: For 2008, the maximum predicted biomass of an isolated individual was 0.18 and $0.28 \mathrm{~g} /$ plant for cheatgrass and medusahead, respectively (Tables 1 and 2) and it increased to 12 and 23 times for cheatgrass and medusahead, respectively in 2009. However, models for predicting biomass per plant were non-significant $(P>0.05)$ for both species. Both cheatgrass and medusahead biomass was not influenced by intra- or inter-specific competition ( $P>0.05$, Tables 1 and 2$)$. Similarly for perennial species, the models resulted in nonsignificant regression coefficients $(P>0.05$, Table 3 and 4$)$ for predicting maximum biomass per plant. Similar trends were observed for both 2008 and 2009 for bluebunch wheatgrass. However, Sandberg's bluegrass plants died and no seedlings survived to 2009. For both years, addition of intra- or inter-specific competition had no influence on biomass of bluebunch wheatgrass or Sandberg's bluegrass 
Table 1. Multiple linear regression predicting individual cheatgrass shoot biomass (Wc; g/plant) using seeding, initial and final densities as independent variables for 2008 and 2009.

\begin{tabular}{|c|c|c|c|c|c|c|c|c|c|}
\hline $\begin{array}{l}\text { Dependent } \\
\text { Variable } \\
\end{array}$ & \begin{tabular}{|l|} 
Plant \\
Species
\end{tabular} & Year & $\begin{array}{l}\begin{array}{l}\text { Independent } \\
\text { variable }\end{array} \\
\end{array}$ & $\beta_{0 c}$ & $\beta_{\mathrm{cc}}$ & $\beta_{\mathrm{cm}}$ & $\beta_{\mathrm{cb}}$ & $\beta_{\mathrm{cs}}$ & $\mathrm{R}^{2}$ \\
\hline \multirow{7}{*}{$\mathrm{W}_{\mathrm{c}}$} & \multirow{7}{*}{ Cheatgrass } & \multirow{3}{*}{2008} & $\begin{array}{l}\text { Seeding } \\
\text { density }\end{array}$ & $0.18(0.03)$ & $-0.0001(0.0001)$ & $0.0001(0.0001)$ & $-0.0001(0.0001)$ & $0.0(0.0001)$ & 0.009 \\
\hline & & & Initial density & $0.17(0.03)$ & $0.0001(0.0006)$ & $-0.0002(0.0006)$ & $0.0001(0.001)$ & $0.006(0.009)$ & 0.003 \\
\hline & & & Final density & $0.18(0.03)$ & $0.0009(0.001)$ & $-0.001(0.0006)$ & $0.01(0.004)$ & $-0.02(0.06)$ & 0.059 \\
\hline & & \multirow{4}{*}{2009} & & & & & & & \\
\hline & & & $\begin{array}{l}\text { Seeding } \\
\text { density }\end{array}$ & $2.34(0.41)$ & $-0.0008(0.001)$ & $-0.002(0.001)$ & $-0.0011(0.001)$ & $0.002(0.001)$ & 0.042 \\
\hline & & & Initial density & $2.21(0.47)$ & $-0.002(0.02)$ & $-0.01(0.009)$ & $-0.04(0.06)$ & $0.63(1.05)$ & 0.009 \\
\hline & & & Final density & $2.71(0.54)$ & $0.1(0.09)$ & $-0.13(0.04)$ & $-0.02(0.01)$ & & 0.039 \\
\hline
\end{tabular}

Table 2. Multiple linear regression predicting individual medusahead shoot biomass $\left(\mathrm{W}_{\mathrm{m}}\right.$; $\left.\mathrm{g} / \mathrm{plant}\right)$ using seeding, initial and final densities as independent variables for 2008 and 2009.

\begin{tabular}{|c|c|c|c|c|c|c|c|c|c|}
\hline $\begin{array}{l}\text { Dependent } \\
\text { Variable }\end{array}$ & \begin{tabular}{|l} 
Plant \\
Species
\end{tabular} & Year & $\begin{array}{l}\text { Independent } \\
\text { variable }\end{array}$ & $\beta_{0 \mathrm{~m}}$ & $\beta_{\mathrm{mm}}$ & $\beta_{\mathrm{mc}}$ & $\beta_{\mathrm{mb}}$ & $\beta_{\mathrm{ms}}$ & $\mathrm{R}^{2}$ \\
\hline \multirow{6}{*}{$\mathrm{W}_{\mathrm{m}}$} & \multirow{6}{*}{ Medusahead } & \multirow{3}{*}{2008} & $\begin{array}{l}\text { Seeding } \\
\text { density }\end{array}$ & $0.28(0.02)$ & $0.0001(0.00)$ & $-0.0001(0.00)$ & $0.0001(0.00)$ & $0.00(0.00)$ & 0.038 \\
\hline & & & Initial density & $0.28(0.02)$ & $-0.001(0.0004)$ & $-0.0005(0.0004)$ & $0.0(0.001)$ & $0.01(0.006)$ & 0.036 \\
\hline & & & Final density & $0.27(0.02)$ & $-0.0008(0.0004)$ & $0.0003(0.0008)$ & $-0.004(0.003)$ & $-0.05(0.05)$ & 0.028 \\
\hline & & \multirow{3}{*}{2009} & $\begin{array}{l}\text { Seeding } \\
\text { density }\end{array}$ & $6.55(1.16)$ & $-0.002(0.003)$ & $-0.001(0.003)$ & $-0.003(0.003)$ & $-0.0001(0.003)$ & 0.019 \\
\hline & & & Initial density & $5.80(1.29)$ & $-0.01(0.03)$ & $-0.02(0.04)$ & $-0.12(0.17)$ & $-0.75(2.92)$ & 0.004 \\
\hline & & & Final density & $9.27(1.49)$ & $-0.32(0.12)$ & $-0.38(0.24)$ & $-0.06(0.041)$ & & 0.047 \\
\hline
\end{tabular}

Table 3. Multiple linear regression predicting individual bluebunch wheatgrass shoot biomass $\left(\mathrm{W}_{\mathrm{b}}\right.$; $\left.\mathrm{g} / \mathrm{plant}\right)$ using seeding, initial and final densities as independent variables for 2008 and 2009.

\begin{tabular}{|c|c|c|c|c|c|c|c|c|c|}
\hline $\begin{array}{l}\text { Dependent } \\
\text { variable }\end{array}$ & $\begin{array}{l}\text { Plant } \\
\text { Species }\end{array}$ & Year & $\begin{array}{l}\text { Independent } \\
\text { variable }\end{array}$ & $\beta_{0 \mathrm{~b}}$ & $\beta_{\mathrm{bb}}$ & $\beta_{\mathrm{bm}}$ & $\beta_{\mathrm{bc}}$ & $\beta_{\mathrm{bs}}$ & $\mathrm{R}^{2}$ \\
\hline \multirow{7}{*}{$\mathrm{W}_{\mathrm{b}}$} & \multirow{7}{*}{$\begin{array}{l}\text { Bluebunch } \\
\text { wheatgrass }\end{array}$} & \multirow{3}{*}{2008} & $\begin{array}{l}\text { Seeding } \\
\text { density }\end{array}$ & $0.04(0.03)$ & $0.0(0.0001)$ & $0.0(0.0001)$ & $0.0(0.0001)$ & $0.0(0.0001)$ & 0.0009 \\
\hline & & & Initial density & - & $0.003(0.002)$ & $0.0005(0.0006)$ & $0.0002(0.0006)$ & $0.005(0.009)$ & 0.022 \\
\hline & & & Final density & $0.04(0.03)$ & $0.008(0.004)$ & $-0.0001(0.0006)$ & $-0.0002(0.001)$ & $-0.009(0.07)$ & 0.015 \\
\hline & & & & & & & & & \\
\hline & & \multirow[t]{3}{*}{2009} & $\begin{array}{l}\text { Seeding } \\
\text { density }\end{array}$ & $0.42(0.21)$ & $0.0(0.0005)$ & $-0.0003(0.0005)$ & $0.0(0.0005)$ & - & 0.002 \\
\hline & & & Initial density & $0.52(0.23)$ & $-0.002(0.03)$ & $-0.004(0.005)$ & $-0.005(0.009)$ & & 0.004 \\
\hline & & & Final density & $0.48(0.27)$ & $-0.002(0.007)$ & $-0.012(0.02)$ & $-0.009(0.04)$ & & 0.002 \\
\hline
\end{tabular}

Table 4. Multiple linear regression predicting individual Sandberg's bluegrass shoot biomass $\left(\mathrm{W}_{\mathrm{s}}\right.$; g/plant) using seeding, initial and final densities as independent variables for 2008 and 2009.

\begin{tabular}{|c|c|c|c|c|c|c|c|c|c|}
\hline $\begin{array}{l}\begin{array}{l}\text { Dependent } \\
\text { variable }\end{array} \\
\end{array}$ & \begin{tabular}{|l} 
Plant \\
Species \\
\end{tabular} & Year & $\begin{array}{l}\begin{array}{l}\text { Independent } \\
\text { variable }\end{array} \\
\end{array}$ & $\beta_{0 \mathrm{~s}}$ & $\beta_{\mathrm{ss}}$ & $\beta_{\mathrm{sm}}$ & $\beta_{\mathrm{sc}}$ & $\beta_{\mathrm{sb}}$ & $\mathrm{R}^{2}$ \\
\hline \multirow{7}{*}{$\mathrm{W}_{\mathrm{s}}$} & \multirow{7}{*}{$\begin{array}{l}\text { Sandberg's } \\
\text { bluegrass }\end{array}$} & \multirow{3}{*}{2008} & $\begin{array}{l}\text { Seeding } \\
\text { density }\end{array}$ & $\begin{array}{l}0.001(0.000 \\
7)\end{array}$ & $0.0(0.0)$ & $0.0(0.0)$ & $0.0(0.0)$ & $0.0(0.0)$ & 0.004 \\
\hline & & & Initial density & $\begin{array}{l}0.001(0.000 \\
8)\end{array}$ & $0.0(0.0)$ & $0.0(0.0)$ & $0.0(0.0)$ & $0.0(0.0002)$ & 0.006 \\
\hline & & & Final density & $\begin{array}{l}- \\
0.0002(0.00 \\
04)\end{array}$ & $0.0(0.0)$ & $0.0(0.0)$ & $0.0(0.0)$ & $0.02(0.001)$ & 0.06 \\
\hline & & & & & & & & & \\
\hline & & \multirow{3}{*}{2009} & $\begin{array}{l}\text { Seeding } \\
\text { density }\end{array}$ & & & & & & \\
\hline & & & Initial density & & & & & & \\
\hline & & & Final density & & & & & & \\
\hline
\end{tabular}

Note: For Table 1 to 4 - Competition coefficients $(\beta)$ represent the per plant weight change in response to a single plant increase in density; Numbers in parentheses are standard errors for coefficients. No Sandberg's bluegrass survived in 2009. 


\section{$(P>0.05$, Tables 3 and 4$)$}

Initial seedling density predicting target plant biomass: Both annual species showed a greater increase in maximum predicted biomass for 2009 compared to 2008 with cheatgrass resulting in an increase of $2.03 \mathrm{~g} /$ plant. During 2009, similar results were found for both annuals and bluebunch wheatgrass (no Sandberg's bluegrass seedlings survived).

Final seedling density predicting target plant biomass: In 2009, cheatgrass and medusahead biomass per plant were 15 and 35 times greater $(P<0.05)$ than compared to 2008 . Intraspecific competition coefficients for cheatgrass increased from 0.0009 in 2008 to 0.1 in 2009 while they increased from 0.0008 to 0.33 for medusahead (Tables 1 and 2). However, as with seeding and initial density, for both years, cheatgrass and medusahead biomass was not affected by either intra- or inter-specific competition $(P>0.05)$. Similarly, competition did not influence biomass of either native plant species.

\section{Survivorship}

Seeding density predicting survivorship: Both annual species and bluebunch wheatgrass showed an increase in maximum predicted survivorship for 2009 compared to 2008. However, the models for predicting survivorship were non-significant for these species for both years $(P>0.05)$. Similarly, intra- or inter-specific competition had no influence on survivorship of both annual and perennial species in 2008 and both annual species and bluebunch wheatgrass in 2009 ( $P>0.05$, no Sandberg's bluegrass seedlings survived in 2009).

\section{Competition Importance and Survivorship $R^{2}$}

Biomass of all species was not significantly influenced by either seeding, initial or final density in any year (Tables 14). The highest $R^{2}$ observed in any of the models was less than 0.06. Similarly, survivorship was not significantly influenced by seeding density in any year and all $\mathrm{R}^{2}$ were less than 0.05 .

\section{Discussion and conclusions}

Contrary to our first hypothesis, we found no evidence that intensity of intra- or inter-specific competition were significant for the first two years species were establishing, regardless of the density (seeding, initial or final density) used as the independent variable. Lack of competition in our study is in agreement with research showing no net plant-plant interactions for available water and nutrients with desert shrubs (Donovan and Richards 2000).

We accepted our hypothesis that competition would be unimportant among invasive and native species in relation to other sources of variation in individual fitness. Since our $\mathrm{R}^{2}$ s $\mathrm{s}$ were below 0.06 , we found little, if any evidence that competitive interactions were important in influencing target plant biomass and survivorship within the range of environmental conditions encountered in the current study. Given the lack of competition intensity observed, it was predictable that competition importance would not be detectable either. A possible explanation for these results could be the harsh and fluctuating environmental conditions at our study site. Such stressful environments can influence establishment, survival and growth of plant species (Ackerman, 1979). Goldberg and Novoplansky (1997) hypothesized that competition will be unimportant in stressful environments: (1) when individual plant survival is primarily determined by conditions between resources pulses; and (2) soil resource availability during interpulse intervals is largely independent of plant density, i.e. abiotically driven. This scenario may apply to our site, where plant survival is largely linked to plant tolerance of drought and temperature extremes. We speculate that environmental conditions in our system are more important than competition in determining plant establishment and dominance.

Taken together, our results indicate that neither the intensity of competition nor the importance of competition explained variation in target plant biomass and survivorship for the first two years plants were establishing in resource poor environments within the semi-arid steppe. Instead abiotic factors may have an overriding influence on plant biomass and survivorship. We propose four scenarios which may apply to semi-arid environments during the initial phase of restoration. First, competition may be both intense and important if competition with neighbors negatively influences plant biomass and thus, plant survival (Goldberg and Barton 1992). Second, competition may not be intense but important if target plant biomass is affected only by competition (Briones et al. 1996). In these two situations, which are unlikely to occur in resource poor environments, managers will likely need to minimize competition. Third, competition may be intense, but not necessarily important if the amount of overall variation in fitness it accounted for is low (Sheley and Larson 1995). Fourth, competition is neither intense nor an important variable when plant survival is largely linked to plant tolerance of drought and temperature extremes, i.e. when survivorship is abiotically driven (Armas et al. 2009; Hobbie et al. 1999). The last two scenarios are likely to occur in resource poor systems. In these situations, competition can range from non-existent to intense, but will not likely be important. This suggests that land managers may be more successful at restoration by overcoming the barriers associated with plant establishment other than competition in resource poor systems, such as abiotic factors, rather than focusing on treatments aimed at controlling invasive plants.

\section{References}

Ackerman TL (1979) Germination and survival of perennial plant species in the Mojave Desert. The Southwest Naturalist 24, 399-408.

Allen EB (1989) The restoration of disturbed arid landscapes with special reference to mycorrhizal fungi. Journal of Arid Environments 17, 279-286.

Armas C, Kikvidze Z, Pugnaire FI (2009) Abiotic conditions, neighbor interactions, and the distribution of Stipa tenacissima in a semiarid mountain range. Journal of Arid Environments 73, 1084-1089.

Briones O, Montana M, Ezcurra E (1996) Competition between three Chihuahuan desert species: evidence from plant sizedistance relations and root distribution. Journal of Vegetation Science 7, 453-460.

Brooker RW, Kikividze Z (2008) Importance: an overlooked concept in plant interaction research. Journal of Ecology 96, 
703-708.

D'Antonio CM, Vitousek PM (1992) Biological invasions by exotic grasses, the grass/fire cycles, and global change. Annual Review of Ecology and Systematics 23, 63-87.

Donovan LA, Richards JH (2000) Juvenile shrubs show differences in stress tolerance, but no competition or facilitation, along a stress gradient. Journal of Ecology 88, 116.

Goldberg DE, Barton AM (1992) Patterns and consequences of interspecific competition in natural communities: a review of field experiments with plants. American Naturalist 139, 771801.

Goldberg DE, Novoplansky A (1997) On the relative importance of competition in unproductive environments. Journal of Ecology 85, 409-418.

Grace JB (1991) A clarification of the debate between Grime and Tilman. Functional Ecology 5, 583-587.

Grime JP (1973) Competitive exclusion in herbaceous vegetation. Nature 242, 344-347.

Hobbie S, Shevtsova A, Chapin F (1999) Plant responses to species removal and experimental warming in Alaskan tussock tundra. Oikos 84, 417-434.
Humphrey LD, Schupp EW (2004) Competition as a barrier to establishment of a native perennial grass (Elymus elymoides) in alien annual grass (Bromus tectorum) communities. Journal of Arid Environments 58, 405-422.

Newman EI (1973) Competition and diversity in herbaceous vegetation. Nature 244, 310.

Sheley RL, Larson LL (1995) Interference between cheatgrass and yellow starthistle at 3 soil depths. Journal of Range Management 48, 392-397.

Spitters CJT (1983) An alternative approach to the analysis of mixed cropping experiments. 1. Estimation of competition effects. Netherlands Journal of Agricultural Science 31, 111.

Tikka PM, Heikkila T, Heiskanen M, Kuitunen M (2001) The role of competition and rarity in restoration of a dry grassland in Finland. Applied Vegetation Science 4, 139-146.

Tilman D (1980) Resources: a graphical mechanistic approach to competition and predation. American Naturalist 116, 362393.

Welden CW, Slauson WL (1986) The intensity of competition versus its importance, and overlooked distinction and some implications. The Quarterly Review of Biology 61, 23-44. 